\title{
Vitamin D prohormone in the treatment of secondary hyperparathyroidism in patients with chronic kidney disease
}

This article was published in the following Dove Press journal: International Journal of Nephrology and Renovascular Disease II May 2017

Number of times this article has been viewed

\author{
Claudia Friedl' \\ Emanuel Zitt ${ }^{2}$ \\ 'Department of Internal Medicine, \\ Clinical Division of Nephrology, \\ Medical University of Graz, Graz, \\ ${ }^{2}$ Department of Nephrology and \\ Dialysis, Feldkirch Academic Teaching \\ Hospital, Feldkirch, Austria
}

\begin{abstract}
Secondary hyperparathyroidism (sHPT) represents the adaptive and very often, finally, maladaptive response of the organism to control the disturbed homeostasis of calcium, phosphorus, and vitamin D metabolism caused by declining renal function in chronic kidney disease (CKD). sHPT leads to cardiovascular and extravascular calcifications and is directly linked to an increased risk of cardiovascular morbidity and mortality as well as excess all-cause mortality. Vitamin D plays an important role in the development of sHPT. CKD patients are characterized by a high prevalence of hypovitaminosis D. Supplementation with both vitamin D prohormones cholecalciferol and ergocalciferol enables the achievement and maintenance of a normal vitamin $\mathrm{D}$ status when given in adequate doses over an appropriate treatment period. In patients with earlier stages of CKD, sHPT is influenced by and can be successfully treated with vitamin D prohormone supplementation, whereas in patients with very late stages of CKD and those requiring dialysis, treatment with prohormones seems to be of limited efficacy. This review gives an overview of the pathogenesis of sHPT, summarizes vitamin D metabolism, and discusses the existing literature regarding the role of vitamin D prohormone in the treatment of sHPT in patients with CKD.
\end{abstract}

Keywords: cholecalciferol, CKD, CKD-MBD, dialysis, ergocalciferol, SHPT.

\section{Pathogenesis of secondary hyperparathyroidism (sHPT) in chronic kidney disease (CKD)}

sHPT represents the adaptive and very often, finally, maladaptive response of the organism to control the disturbed homeostasis of calcium, phosphorus, and vitamin $\mathrm{D}$ metabolism caused by declining renal function in CKD. These disturbances in mineral metabolism lead to vascular ${ }^{1,2}$ and valvular ${ }^{3}$ calcifications and are directly linked to an increased risk of cardiovascular morbidity and mortality as well as excess all-cause mortality. ${ }^{4}$ Apart from extra-skeletal side effects, sHPT also leads to profound alterations in bone metabolism, which become obvious in the different forms of renal osteodystrophy. ${ }^{5}$ This clinical syndrome encompassing mineral, bone, and cardiovascular abnormalities has been termed "CKD-related mineral and bone disorder" (CKD-MBD). ${ }^{6}$ sHPT generally develops in CKD stage 3 with an estimated glomerular filtration rate (GFR) $<60 \mathrm{~mL} / \mathrm{min} / 1.73 \mathrm{~m}^{2}$, and its prevalence increases as kidney function declines. ${ }^{78}$ Initially, it is characterized by normocalcemia with intermittent transient hypocalcemia, fasting normo- or hypophosphatemia, and reduced $1,25(\mathrm{OH})_{2} \mathrm{D}_{3}$ (calcitriol) concentration, together with increasing levels of fibroblast growth factor 23 (FGF23), a decrease in plasma soluble Klotho, and the development of renal osteodystrophy. ${ }^{8-11}$ These alterations result in increased secretion
Department of Nephrology and Dialysis, Feldkirch Academic Teaching Hospital, Carinagasse 47, 6800 Feldkirch, Austria Tel +4355223032700

$\mathrm{Fax}+4355223037506$

Email emanuel.zitt@lkhf.at
International Journal of Nephrology and Renovascular Disease 2017:10 109-122

109 
and synthesis of parathyroid hormone (PTH) and parathyroid cell hyperplasia (Figure 1). ${ }^{12}$ The precise sequence of metabolic alterations in early CKD leading to sHPT still remains a matter of debate. Traditionally, retention of phosphorus with accompanying reduction in ionized calcium due to decreasing GFR was considered to be the primary event in the pathogenesis of sHPT. These transient metabolic changes would induce an increase in PTH, which would rapidly correct these alterations due to a decreased tubular reabsorption of phosphorus and increased tubular calcium reabsorption. A new steady state is reached at the expense of the development of hyperparathyroidism. This concept was originally described with the "trade-off hypothesis" by Slatopolsky et al. ${ }^{13}$ The discovery of phosphatonin FGF23 as a key player in the control of phosphorus metabolism changed and broadened the conceptual framework. This bone-derived protein decreases serum phosphorus concentration by reducing tubular phosphorus reabsorption independent of PTH. In contrast to PTH (which stimulates tubular $1 \alpha$-hydroxylase activity), FGF23 decreases the synthesis of calcitriol in the kidney. To activate its membranebound receptors FGFR-1 and FGFR-3 on tubular cells, it requires the presence of its co-receptor Klotho. ${ }^{14}$ Clinical as well as animal model studies suggest that FGF23 levels increase earlier than PTH in CKD. ${ }^{9,15}$ More recent data found that vitamin D status critically determines the order of FGF23 or PTH elevation. Whereas in vitamin D-replete patients with CKD stage 3, FGF23 levels were elevated in a greater proportion of patients compared with PTH over all GFR strata, in vitamin D insufficient patients, the opposite pattern with an earlier increase in PTH was found. ${ }^{16}$ Reduced renal Klotho expression and synthesis might even precede the raise of FGF23. ${ }^{17,18}$ With progressive CKD renal Klotho expression and levels of soluble Klotho decrease. ${ }^{19,20} \mathrm{PTH}$ increases FGF23 synthesis directly through the activation of its receptor PTH-R1 and the orphan nuclear receptor Nurr1 and indirectly through an increased calcitriol synthesis stimulating renal tubular $1 \alpha$-hydroxylase. ${ }^{21-23}$ In contrast,

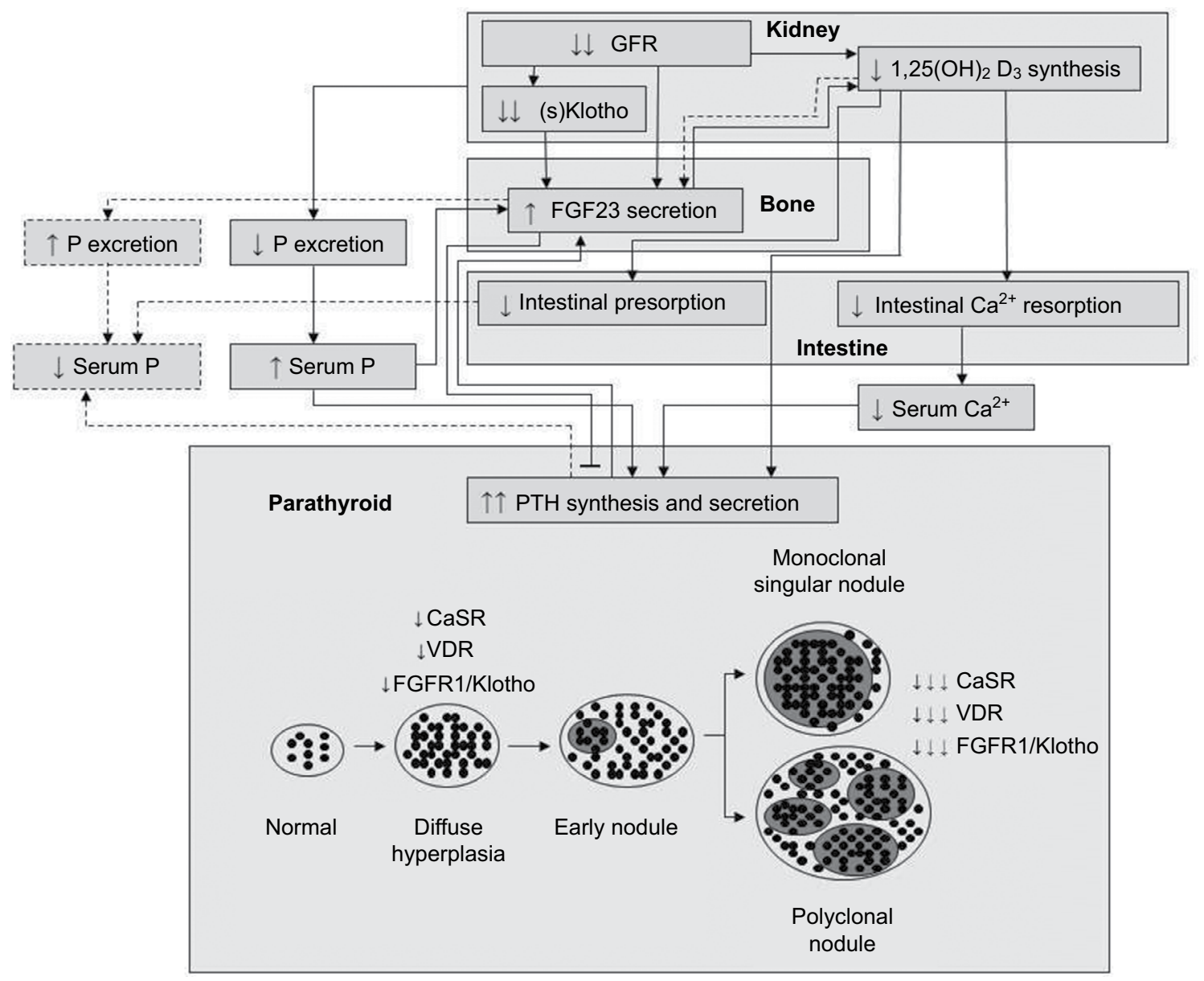

Figure I Pathogenesis of secondary hyperparathyroidism in chronic kidney disease.

Notes: Dashed lines indicate counter-regulatory pathways.

Abbreviations: CaSR, calcium-sensing receptor; FGF23, fibroblast growth factor 23; FGFRI, fibroblast growth factor receptor I; GFR, glomerular filtration rate; VDR, vitamin D receptor; (s) Klotho, soluble Klotho; PTH, parathyroid hormone. 
FGF23 inhibits PTH synthesis and secretion, although this effect is diminished in CKD due to a reduced expression of Klotho and FGFR-1 on parathyroid cells. ${ }^{24-26}$

\section{Vitamin D deficiency}

Vitamin D plays a key role in the regulation of mineral and bone metabolism. Vitamin D deficiency is an important component in the pathogenesis of sHPT, which is defined as a reduced serum level of $25(\mathrm{OH}) \mathrm{D}$ and is common in the general population with significantly higher prevalence in patients with $\mathrm{CKD} .{ }^{27,28}$ Compared to patients with normal renal function, impaired kidney function was associated with a $32 \%$ higher risk for vitamin D deficiency. ${ }^{28}$ It develops early in the course of CKD and its prevalence increases with the progressive loss of renal function. ${ }^{29}$ In a study conducted by LaClair et al, only $29 \%$ and $17 \%$ of patients with CKD stage 3 and 4, respectively, had sufficient vitamin D levels, defined as a serum $25(\mathrm{OH}) \mathrm{D}$ concentration $>30 \mathrm{ng} / \mathrm{mL} .{ }^{30} \mathrm{In}$ hemodialysis patients, $76 \%-94 \%$ were found to have $25(\mathrm{OH})$ $\mathrm{D}<30 \mathrm{ng} / \mathrm{mL} \cdot{ }^{31-35} \mathrm{~A}$ high prevalence of vitamin D deficiency of $87 \%$ was also observed in a large cohort of peritoneal dialysis patients. ${ }^{36}$ Studies have shown that African-Americans have lower $25(\mathrm{OH}) \mathrm{D}$ levels compared with whites. The reasons for this finding seem to be multifactorial and are not completely clarified yet. ${ }^{37}$

Vitamin D deficiency is associated with elevated PTH in the general population as well as in patients with CKD. ${ }^{30,32,38-40}$ Gonzalez et al found a significant negative correlation between vitamin D levels and intact PTH (iPTH) in patients with CKD stage $1-5.4^{40}$ These findings are consistent with those from a US cross-sectional study, which revealed an inverse relationship between $25(\mathrm{OH}) \mathrm{D}$ and iPTH levels in CKD 3 and $4 .{ }^{30}$ In a prospective cohort study, 25(OH)D levels correlated better with iPTH in patients with CKD 1-5, than did 1,25(OH) 2 D. ${ }^{29}$ Even in end-stage renal disease, vitamin $\mathrm{D}$ deficiency is associated with high PTH. ${ }^{32,41}$

To date, there is no consensus on optimal serum levels of $25(\mathrm{OH}) \mathrm{D}$ in the general population as well as in $\mathrm{CKD} .^{38}$ Since, in non-CKD patients, 25(OH)D levels $<30 \mathrm{ng} / \mathrm{mL}$ are associated with an increase in PTH concentrations, most experts define 25(OH)D concentrations from 20 to $29 \mathrm{ng} /$ $\mathrm{mL}$ as vitamin $\mathrm{D}$ insufficiency and $25(\mathrm{OH}) \mathrm{D}<20 \mathrm{ng} / \mathrm{mL}$ as vitamin D deficiency. ${ }^{38}$ However, compared to the general population, sHPT in CKD is more distinct and the pathogenesis is multifactorial, as described earlier. Therefore, whether optimal $25(\mathrm{OH}) \mathrm{D}$ levels for patients with CKD are the same as for the general population is a matter of debate. A recently published cross-sectional study conducted in
$>14,200$ patients with CKD stage $1-5$ revealed an inverse relationship between $25(\mathrm{OH}) \mathrm{D}$ and $\mathrm{iPTH}$ in all five CKD stages. ${ }^{42}$ Interestingly, $25(\mathrm{OH}) \mathrm{D}$ levels $>42-48 \mathrm{ng} / \mathrm{mL}$ did not result in further $\mathrm{PTH}$ reduction, suggesting a higher threshold for optimal $25(\mathrm{OH}) \mathrm{D}$ levels in $\mathrm{CKD}$ patients than in the general population. ${ }^{42}$

\section{Vitamin D terminology}

Technically, vitamin D is not a vitamin, since it is not an essential dietary factor and is synthesized endogenously in the skin. However, vitamin D also meets the criteria of a vitamin, since humans can derive their vitamin $\mathrm{D}$ requirement through the diet. ${ }^{38,43}$ Vitamin D itself has no significant biological activity and has to be transformed into the active form $1,25(\mathrm{OH})_{2} \mathrm{D}$ to exert significant physiological actions. The characteristics of $1,25(\mathrm{OH})_{2} \mathrm{D}$ are those of a hormone, and consequently vitamin $\mathrm{D}$ could be considered a prohormone. ${ }^{44}$ The effect of $1,25(\mathrm{OH})_{2} \mathrm{D}$ depends on the adequate availability of $25(\mathrm{OH}) \mathrm{D}$, which in turn depends on an appropriate vitamin D nutritional status. The terminology used to describe various forms of vitamin $\mathrm{D}$ is confusing and non-uniform. The nomenclature of the two major forms of vitamin D and their metabolites is presented in Table 1.

\section{Vitamin D sources}

Vitamin D is a group of fat-soluble secosterols with several existing forms. The major compounds in humans are vita$\min \mathrm{D}_{3}$ (cholecalciferol) and vitamin $\mathrm{D}_{2}$ (ergocalciferol). ${ }^{38}$ Sunlight-induced synthesis of vitamin $\mathrm{D}_{3}$ in the skin is the primary source of vitamin D in humans; $~ 90 \%$ of the requirement results from sunlight exposure. ${ }^{45}$ Vitamin D can also be obtained from dietary sources. However, these sources are limited, since only a few foods (eg oily fish, fish liver oils) naturally contain vitamin $\mathrm{D}$. Food sources of vitamin $\mathrm{D}_{2}$, the plant-derived form of vitamin D, are very limited, and wild mushrooms are one of the significant sources. Further sources of dietary vitamin D are fortified foods and supplements. ${ }^{38,45}$ Both vitamin $\mathrm{D}_{2}$ and $\mathrm{D}_{3}$ are used in fortification and as dietary supplements. Although vitamin $\mathrm{D}_{2}$ is the major compound used in the USA, vitamin $\mathrm{D}_{3}$ is mainly used in Europe. ${ }^{46}$

\section{Vitamin D metabolism}

The cutaneous synthesis of vitamin $\mathrm{D}_{3}$ is a non-enzymatic process. The absorption of UVB radiation $(290-315 \mathrm{~nm})$ results in the conversion of 7-dehydrocholesterol to previtamin $\mathrm{D}_{3}$ followed by thermal isomerization to vitamin $\mathrm{D}_{3} \cdot{ }^{45}$ Dietary vitamin $\mathrm{D}$ and endogenously synthesized vitamin $\mathrm{D}_{3}$ enter the circulation. Vitamin $\mathrm{D}$ can be stored in and 
Table I Vitamin D terminology

\begin{tabular}{|c|c|c|c|}
\hline & Vitamin $D_{2}$ and metabolites & Vitamin $D_{3}$ and metabolites & Collective terminology \\
\hline \multicolumn{4}{|l|}{ Prohormone } \\
\hline $\begin{array}{l}\text { Abbreviation } \\
\text { Full term } \\
\text { Synonym }\end{array}$ & $\begin{array}{l}\mathrm{D}_{2} \\
\text { Vitamin } \mathrm{D}_{2} \\
\text { Ergocalciferol }\end{array}$ & $\begin{array}{l}\mathrm{D}_{3} \\
\text { Vitamin } \mathrm{D}_{3} \\
\text { Cholecalciferol }\end{array}$ & $\begin{array}{l}\text { D } \\
\text { Vitamin D }\end{array}$ \\
\hline $\begin{array}{l}\text { Prehormone } \\
\text { (product of } \mathrm{I}^{\mathrm{st}}\end{array}$ & & & \\
\hline $\begin{array}{l}\text { Abbreviation } \\
\text { Full term } \\
\text { Synonym }\end{array}$ & $\begin{array}{l}25(\mathrm{OH}) \mathrm{D}_{2} \\
25 \text {-Hydroxyvitamin } \mathrm{D}_{2} \\
\text { Ercalcidiol }\end{array}$ & $\begin{array}{l}25(\mathrm{OH}) \mathrm{D}_{3} \\
25-\mathrm{Hydroxy} \text { vitamin } \mathrm{D}_{3} \\
\text { Calcidiol }\end{array}$ & $\begin{array}{l}\text { 25(OH)D } \\
\text { 25-Hydroxyvitamin D }\end{array}$ \\
\hline $\begin{array}{l}\text { Hormone } \\
\text { (product of } 2^{n}\end{array}$ & & & \\
\hline $\begin{array}{l}\text { Abbreviation } \\
\text { Full term } \\
\text { Synonym }\end{array}$ & $\begin{array}{l}\mathrm{I}, 25(\mathrm{OH})_{2} \mathrm{D}_{2} \\
\mathrm{I}, 25 \text {-Dihydroxyvitamin } \mathrm{D}_{2} \\
\text { Ercalcitriol }\end{array}$ & $\begin{array}{l}\mathrm{I}, 25(\mathrm{OH})_{2} \mathrm{D}_{3} \\
\mathrm{I}, 25 \text {-Dihydroxyvitamin } \mathrm{D}_{3} \\
\text { Calcitriol }\end{array}$ & $\begin{array}{l}\mathrm{I}, 25(\mathrm{OH})_{2} \mathrm{D} \\
\mathrm{I}, 25 \text {-Dihydroxyvitamin } \mathrm{D}\end{array}$ \\
\hline
\end{tabular}

released from fat cells, ${ }^{38}$ whereby vitamin $D_{3}$ is the major stored form of vitamin $\mathrm{D}$ in adipose tissue. ${ }^{47}$ In the circulation vitamin $\mathrm{D}$ is bound to vitamin D-binding protein (DBP), the main transporting protein of vitamin D metabolites. ${ }^{48}$ The process of activation of vitamin $\mathrm{D}$ involves two hydroxylation steps. The first step occurs primarily in liver, where native vitamin $\mathrm{D}$ undergoes hydroxylation of carbon 25 by cytochrome P450 enzymes, resulting in the formation of $25(\mathrm{OH})$ D. Several cytochrome P450 enzymes, including CYP2R1 and CYP27A1, have been shown to 25-hydroxylate vitamin D. However, CYP2R1 seems to be the key enzyme responsible for the formation of $25(\mathrm{OH}) \mathrm{D} .^{49,50}$ The 25 -hydroxylation of vitamin $\mathrm{D}$ is not significantly regulated and depends on substrate availability. $25(\mathrm{OH}) \mathrm{D}$ is the major circulating form of vitamin D. ${ }^{48}$ After its synthesis in liver, it is transported by DBP to kidneys. The DBP-25(OH)D complex is filtered by the glomerulus, followed by receptor-mediated re-uptake at the brush border of proximal renal tubular cells involving megalin and cubilin..$^{51,52}$ There, $25(\mathrm{OH}) \mathrm{D}$ is then hydroxylated to $1,25(\mathrm{OH})_{2} \mathrm{D}$. This second hydroxylation is catalyzed by the enzyme $1 \alpha$-hydroxylase (also known as CYP27B1). In contrast to the hepatic 25 -hydroxylases, the renal $1 \alpha$-hydroxylase is substrate-independent under normal conditions. ${ }^{48}$ The production of $1,25(\mathrm{OH})_{2} \mathrm{D}$ in kidneys is tightly regulated by several factors, including serum phosphorus, calcium, PTH, FGF23, and 1,25(OH) $)_{2}$ itself. ${ }^{48,53}$ Low serum calcium, low serum phosphorus, and high PTH levels stimulate this enzyme, whereas FGF23 and $1,25(\mathrm{OH})_{2} \mathrm{D}$ inhibit the expression. ${ }^{53}$ The $1 \alpha$-hydroxylase gene is also expressed in several non-renal tissues. Extra-renally produced $1,25(\mathrm{OH})_{2} \mathrm{D}$ primarily exerts local autocrine and paracrine effects. ${ }^{53,54}$ The regulation of this extra-renal $1 \alpha$-hydroxylase differs from that of the renal enzyme and is substrate-dependent. ${ }^{53}$
Effects of $1,25(\mathrm{OH})_{2} \mathrm{D}$ are mediated via binding to the vitamin D receptor (VDR) that is expressed in a large variety of human cells and regulates $\sim 3 \%$ of the human genome. ${ }^{55}$ $25(\mathrm{OH}) \mathrm{D}$ can also directly bind and activate the VDR. Although its affinity for the VDR is 100-200 times lower than that of $1,25(\mathrm{OH})_{2} \mathrm{D}$, it circulates at concentrations 1000-fold higher than serum $1,25(\mathrm{OH})_{2} \mathrm{D}_{\text {levels. }}{ }^{54}$

The enzyme 24-hydroxylase (CYP24A1) is responsible for the catabolism of $25(\mathrm{OH}) \mathrm{D}$ and $1,25(\mathrm{OH})_{2} \mathrm{D}$. Both the metabolites are 24-hydroxylated at carbon 24 by this enzyme, resulting in $24,25(\mathrm{OH})_{2} \mathrm{D}$ and $1,24,25(\mathrm{OH})_{3} \mathrm{D}$, respectively. However, $1,25(\mathrm{OH})_{2} \mathrm{D}$ is the preferred substrate relative to $25(\mathrm{OH}) \mathrm{D}$. $1,24,25(\mathrm{OH})_{3} \mathrm{D}$ has substantial affinity for the VDR and biological activity. ${ }^{48,53} 24$-Hydroxylation is the first step in the catabolism of $25(\mathrm{OH}) \mathrm{D}$ and $1,25(\mathrm{OH})_{2} \mathrm{D}$, followed by oxidation and further hydroxylation ending in the production of the inactive metabolite calcitroic acid. ${ }^{48,53}$ The regulation of 24-hydroxylase in kidney is also tightly controlled in a reciprocal manner to that of $1 \alpha$-hydroxylase. It is induced by $1,25(\mathrm{OH})_{2} \mathrm{D}, \mathrm{FGF} 23$ and inhibited by PTH. ${ }^{48,53}$ By inactivating $25(\mathrm{OH}) \mathrm{D}$ and $1,25(\mathrm{OH})_{2} \mathrm{D}$, this enzyme regulates the concentration of circulating $1,25(\mathrm{OH})_{2} \mathrm{D}$ in two ways: first, via decreasing the substrate availability of $25(\mathrm{OH}) \mathrm{D}$ and, second, via inactivation of $1,25(\mathrm{OH})_{2} \mathrm{D}$ itself. In addition to its expression in kidney, 24-hydroxylase is present in all cells expressing VDR; however, its specific purpose in extra-renal tissues remains to be elucidated. ${ }^{48}$

\section{Impaired vitamin D metabolism in CKD}

CKD affects all key steps of vitamin D metabolism, namely production, activation, and degradation of vitamin $\mathrm{D}$ and its metabolites. It is characterized by both low concentrations 
of $25(\mathrm{OH}) \mathrm{D}$ and low levels of $1,25(\mathrm{OH})_{2} \mathrm{D}^{28}$ There are various reasons for vitamin $\mathrm{D}$ deficiency in $\mathrm{CKD}$, including reduced availability of vitamin D for 25-hydroxylation due to insufficient sun exposure, ${ }^{45,56}$ low dietary vitamin D intake, ${ }^{57}$ impaired intestinal absorption, ${ }^{58}$ impaired hepatic 25-hydroxylation, ${ }^{59}$ loss of 25(OH)D-DBP in case of severe proteinuria, ${ }^{60}$ reduced glomerular filtration of $25(\mathrm{OH})$ D-DBP as a consequence of low GFR, ${ }^{61}$ impaired re-uptake of $25(\mathrm{OH}) \mathrm{D}$ due to reduced renal megalin expression, ${ }^{62}$ and increased degradation of $25(\mathrm{OH}) \mathrm{D}$ induced by high FGF23 concentrations. $^{63}$

Low 25(OH)D levels have been assumed to be a calcitriolindependent risk factor of hyperparathyroidism based on observational data in hemodialysis patients with insufficient sun exposure ${ }^{41}$ and experimental data showing a direct inhibition of PTH production and secretion in bovine parathyroid cells with calcidiol. ${ }^{64}$

Several mechanisms lead to reduced $1,25(\mathrm{OH})_{2} \mathrm{D}$ levels in CKD. In contrast to patients without kidney disease, in those with $\mathrm{CKD}$, the production of $1,25(\mathrm{OH})_{2} \mathrm{D}$ is at least partially substrate-dependent as has been shown in hemodialysis patients with a significant increase in $1,25(\mathrm{OH})_{2} \mathrm{D}_{3}$ levels during a 4-week supplementation of calcidiol. ${ }^{65}$ Furthermore, the reduction of functional renal mass is accompanied by a progressive loss of renal $1 \alpha$-hydroxylase and results in lower calcitriol production. ${ }^{66}$ Moreover, FGF23 reduces $1,25(\mathrm{OH})_{2} \mathrm{D}$ by down-regulating the renal $1 \alpha$-hydroxylase and enhancing the catabolism of $1,25(\mathrm{OH})_{2} \mathrm{D} \cdot{ }^{63}$ The effect of CKD on the regulation of the extra-renal $1 \alpha$-hydroxylase is unclear. ${ }^{67}$ Supplementation with native vitamin D resulted in an increase in $1,25(\mathrm{OH})_{2} \mathrm{D}$ levels even in anephric subjects, suggesting a compensatory activity of the extra-renal system in CKD. ${ }^{67,68}$

\section{sHPT treatment with vitamin D prohormone}

From a pathophysiological aspect, avoidance of vitamin D deficiency early in the course of CKD to prevent or treat mild to moderate sHPT seems reasonable. With progressive CKD and loss of renal $1 \alpha$-hydroxylase (mainly in stage 5 and $5 \mathrm{D}$ ), the importance of the supplementation with vitamin D prohormone for systemic effects declines. There have been several studies with varying designs, investigating the response of cholecalciferol or ergocalciferol treatment on $25(\mathrm{OH}) \mathrm{D}$ concentration and its effect on PTH levels in patients with CKD summarized in two meta-analyses. ${ }^{69,70}$ However, studies are heterogeneous and differ significantly in supplementation compound, dosing, duration of supplementation, and patient characteristics.

\section{Differences between the two vitamin $D$ prohormones vitamin $D_{2}$ and $D_{3}$}

Vitamin $\mathrm{D}_{2}$ and $\mathrm{D}_{3}$ have long been considered equivalent in their clinical activity; however, the current body of literature strongly suggests the preference of vitamin $\mathrm{D}_{3}$ over $\mathrm{D}_{2}$. Several studies in humans have shown that vitamin $\mathrm{D}_{3}$ is more effective than vitamin $\mathrm{D}_{2}$ in raising and maintaining serum $25(\mathrm{OH})$ D concentrations. ${ }^{47,71-74}$ Daily administration of $4000 \mathrm{IU}$ vitamin $\mathrm{D}_{3}$ or $\mathrm{D}_{2}$ for 2 weeks revealed an 1.7 -fold increase in serum $25(\mathrm{OH}) \mathrm{D}$ levels with vitamin $\mathrm{D}_{3} \cdot{ }^{71}$ Armas et al showed that the administration of a single dose of 50,000 IU vitamin $\mathrm{D}_{2}$ or $\mathrm{D}_{3}$ produced similar initial increases in 25(OH)D serum concentrations in healthy men, indicating equivalent absorption. However, in the vitamin $\mathrm{D}_{3}$ group, $25(\mathrm{OH}) \mathrm{D}$ levels continued to rise through day 14 , whereas in the vitamin $\mathrm{D}_{2}$ group, levels decreased again resulting in concentrations indifferent from baseline. The comparison of the area under the curve revealed a $>3$-fold higher potency for vitamin $\mathrm{D}_{3}{ }^{72} \mathrm{~A}$ meta-analysis including seven randomized controlled trials (RCTs) found that vitamin $\mathrm{D}_{3}$ is more effective in raising serum $25(\mathrm{OH}) \mathrm{D}$ levels than vitamin $\mathrm{D}_{2}$. Separate analyses comparing the dosage frequency (bolus vs daily administration) indicated that either administration resulted in higher $25(\mathrm{OH}) \mathrm{D}$ levels with vitamin $\mathrm{D}_{3}$ compared with vitamin $\mathrm{D}_{2} \cdot{ }^{73}$ The same holds true for patients with CKD and end-stage renal disease. ${ }^{75,76}$ An RCT comparing supplementation with vitamin $\mathrm{D}_{2}$ and $\mathrm{D}_{3}(50,000$ IU weekly for 12 weeks) in patients with CKD stage 3-5 revealed a higher increase in $25(\mathrm{OH}) \mathrm{D}$ levels in the vitamin $\mathrm{D}_{3}$ group. ${ }^{76}$ Vitamin $\mathrm{D}_{3}$ was also found to be more effective than vitamin $\mathrm{D}_{2}$ in raising and providing adequate $25(\mathrm{OH}) \mathrm{D}$ levels over 3 months in hemodialysis patients using equal-unit monthly doses of 200,000 IU.75

Several mechanisms contribute to the greater capacity of vitamin $\mathrm{D}_{3}$ to increase and maintain $25(\mathrm{OH}) \mathrm{D}$ concentrations including higher affinity of vitamin $\mathrm{D}_{3}$ and its metabolites to 25-hydroxylase and DBP and differences in 24-hydroxylation. ${ }^{46,77}$ Due to the differences in the bioequivalence of vitamin $\mathrm{D}_{2}$ and $\mathrm{D}_{3}$, this study has summarized prospective observational studies and RCTs, stratified by vitamin $\mathrm{D}$ compound and CKD stages.

\section{Vitamin D prohormone supplementation in CKD stages 3-5}

In light of the fact that vitamin D deficiency is highly prevalent in patients with CKD and is associated with sHPT as well 
as with negative clinical outcomes in observational studies, ${ }^{29,32,33,78}$ current Kidney Disease: Improving Global Outcomes (KDIGO) guidelines on CKD-MBD published in 2009 (update awaited this year) suggest to measure 25(OH)D levels in patients with CKD stages 3-5D and to correct vitamin D deficiency and insufficiency by using treatment strategies for the general population. However, these guidelines provide neither a specific threshold for $25(\mathrm{OH}) \mathrm{D}$ levels to initiate vitamin D supplementation nor an optimal target value. ${ }^{79}$

Regarding treatment of sHPT, KDIGO guidelines suggest that in CKD stages 3-5, patients with iPTH levels above the upper normal limit of the assay should be evaluated for vitamin D deficiency. It is suggested to correct vitamin D deficiency with the supplementation of native vitamin D. It is acknowledged that in CKD stages 3-5, optimal PTH levels are not known. In patients with $\mathrm{CKD} 5 \mathrm{D}$, it is suggested to maintain iPTH levels in the range of 2-9 times the upper normal limit for the assay in use. No recommendations are made for native vitamin D in the treatment of SHPT in dialysis patients. ${ }^{79}$

Current guidelines may be limited because they recommend treatment of sHPT as opposed to prevention. A recent trial reported that ergocalciferol prevented sHPT in children with CKD stage $\geq 2 .{ }^{80}$ As PTH levels remain relatively stable with eGFR values $>60 \mathrm{~mL} / \mathrm{min} / 1.73 \mathrm{~m}^{2}$, a longer supplementation phase and follow-up period might be necessary in the adult CKD population to see a preventive effect of vitamin $\mathrm{D}$ prohormone on the development of sHPT.

Available data indicate a more pronounced decrease in PTH in patients with earlier stages of CKD. Several studies reported a decline of PTH in CKD stage 3, but not in stage $4 .{ }^{70}$ Other studies on vitamin D prohormone supplementation found variable results, some reporting a decrease in PTH levels across different stages of $\mathrm{CKD}^{76,81-86}$ and some reporting no effect. ${ }^{87-93}$ Tables 2 and 3 provide a detailed overview of published prospective studies investigating the effect of either cholecalciferol or ergocalciferol on PTH levels in patients with CKD stages 3-5.

The magnitude of response can vary considerably among individuals. One of the most important determinants of $25(\mathrm{OH}) \mathrm{D}$ response to a given vitamin $\mathrm{D}$ dose is body weight, as with increasing fat mass more vitamin $\mathrm{D}$ is stored in the fat tissue and not available for 25-hydroxylation. ${ }^{94,95}$ Indeed, obesity is associated with hypovitaminosis D in normal and impaired kidney function ${ }^{96,97}$ and negatively affects the response to supplementation..$^{98,99}$

Even high-dose and long-term supplementation of vitamin D prohormones is characterized by an excellent safety profile. Throughout all studies, no increased risk of hypercalcemia or hyperphosphatemia, well known side-effects of active vitamin $\mathrm{D}$ compounds ${ }^{100}$ limiting their use, was observed. In addition, high-dose ergocalciferol supplementation with 50,000 IU weekly over a short term of 6 weeks in patients with CKD 4-5 had no influence on FGF23 concentrations, as shown recently. ${ }^{90}$

Aiming for the prevention and treatment of SHPT in vitamin $\mathrm{D}$ deficient or insufficient patients with $\mathrm{CKD}$, the following approach is suggested: 1) evaluation for vitamin D deficiency or insufficiency measuring 25(OH)D levels; 2) cholecalciferol supplementation in case of a $25(\mathrm{OH}) \mathrm{D}$ level $<30 \mathrm{ng} / \mathrm{mL}$ using a daily (3000-3900 IU or 2800-4000 IU, dependent on the available preparation, eg, 300 or $400 \mathrm{IU} /$ drop) or weekly (20,000-30,000 IU) dosing regimen. These regimens may differ from one country to another due to the availability of pharmaceutical cholecalciferol dosages; 3 ) re-evaluation of 25(OH)D level, PTH, serum calcium, and phosphorus after 3 months. In case of vitamin D sufficiency, it is suggested to halve the cholecalciferol maintenance dose. Otherwise, it has been proposed to continue the initial dose under regular control with thrice-monthly re-evaluation. In the rare event of hypercalcemia or hyperphosphatemia, cholecalciferol supplementation should be temporarily stopped.

In summary, an improvement in sHPT by vitamin D supplementation has been demonstrated in many but not all studies of CKD patients. Several reasons could account for these discrepancies: differences in patient characteristics, different baseline PTH levels prior to supplementation, differences in vitamin D dosing and duration of supplementation, and finally achieved degree of vitamin $\mathrm{D}$ restoration. All these factors may contribute to the lack of congruent findings across studies.

\section{Vitamin D prohormone supplementation in CKD stage 5D (dialyis patients)}

Optimal ranges for $25(\mathrm{OH}) \mathrm{D}$ levels are not known in patients on hemodialysis. Observational studies have shown an association between low 25(OH)D levels and adverse clinical outcomes. ${ }^{32-34}$ Although data from clinical trials are missing to show a survival benefit after increasing $25(\mathrm{OH})$ $\mathrm{D}$ levels in insufficient or deficient hemodialysis patients, current guidelines suggest to replete $25(\mathrm{OH}) \mathrm{D}$ stores in these patients on grounds of low costs and relative and potential therapeutic impact. ${ }^{79}$ The postulated suppression of PTH secretion with the supplementation of vitamin D may be found even in anuric or anephric patients on dialysis, as 


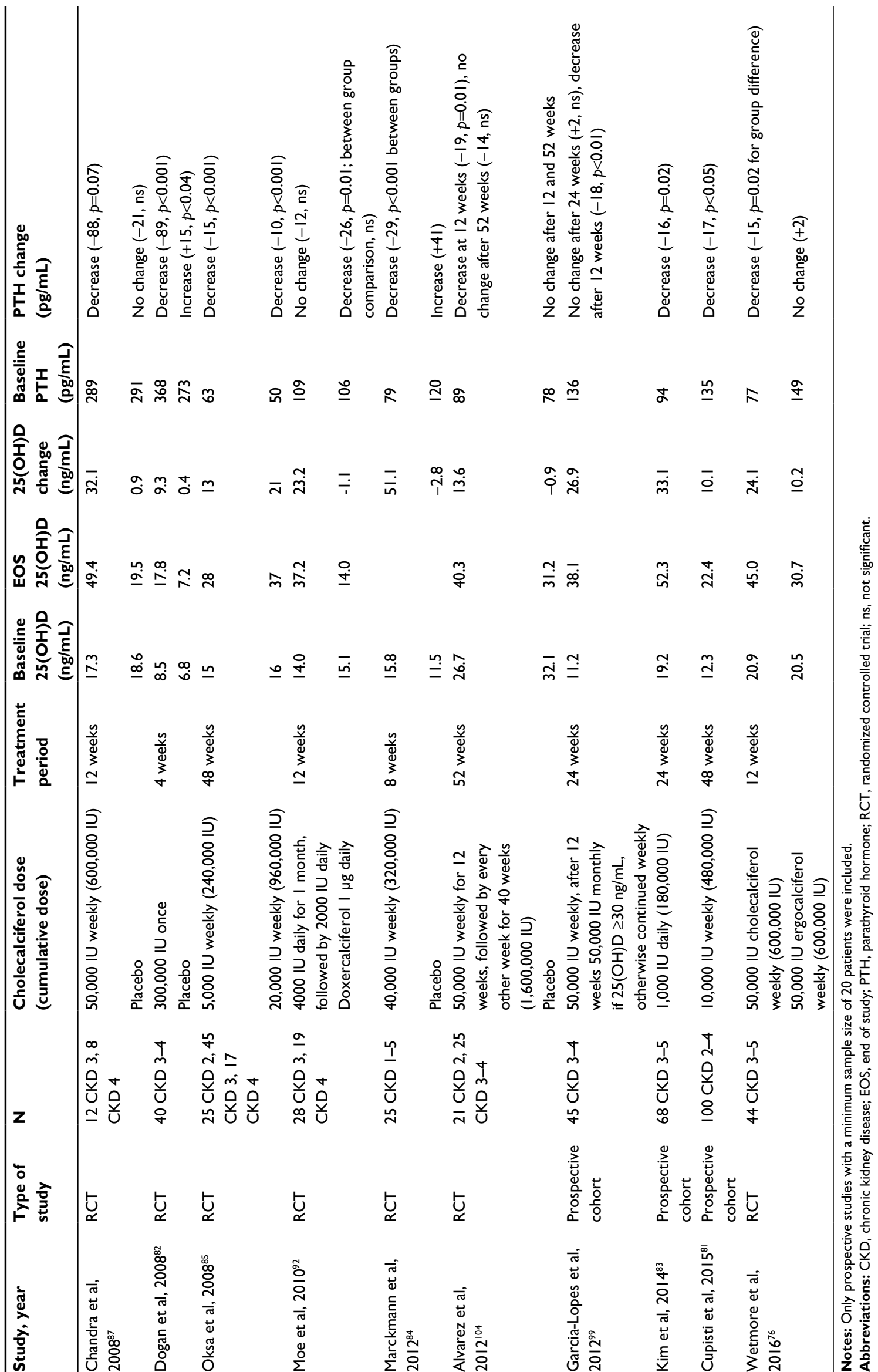




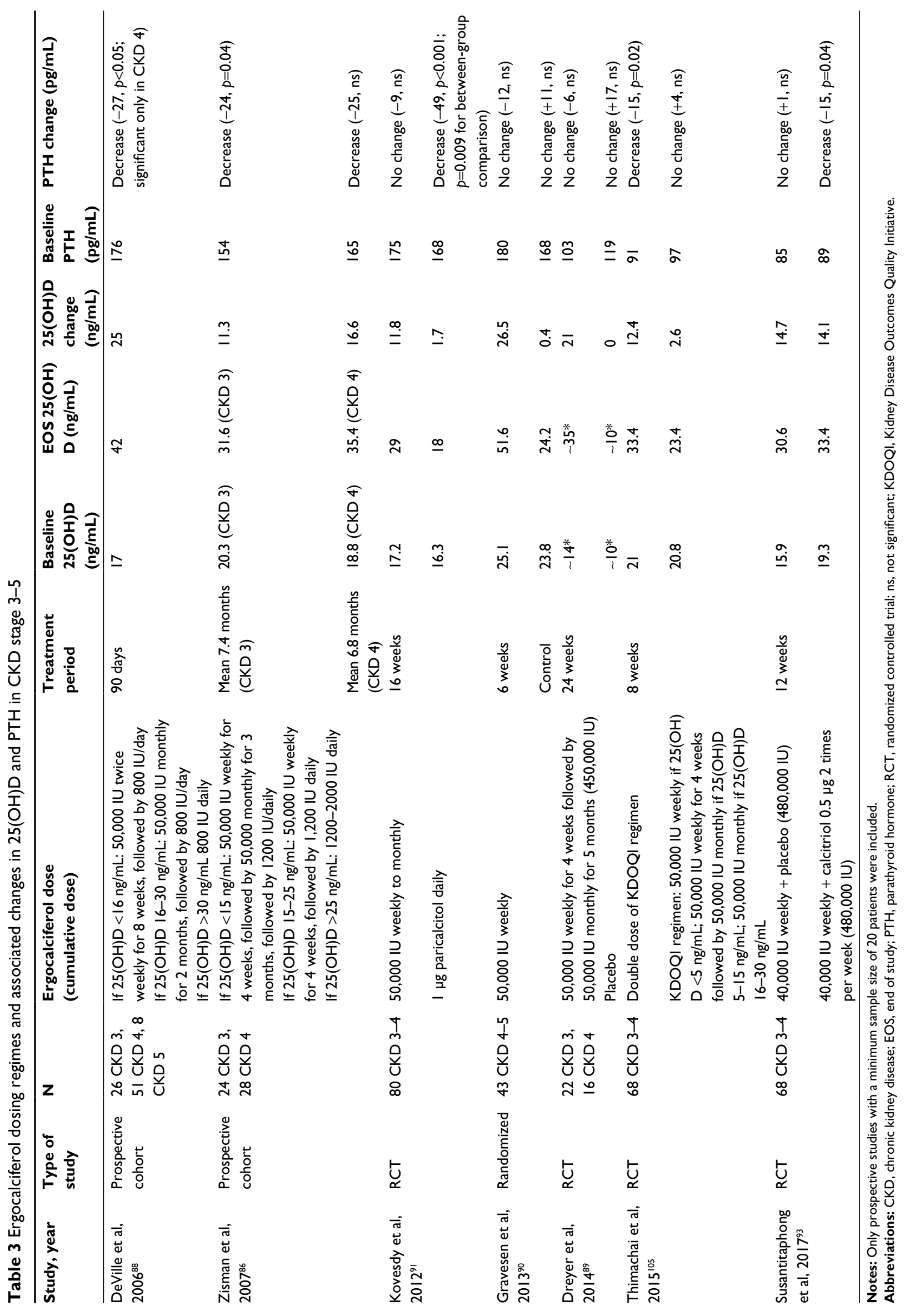




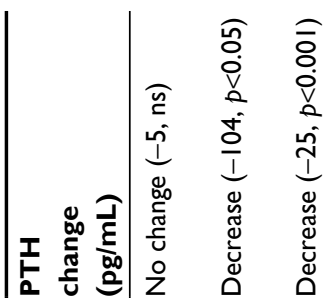

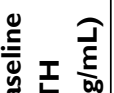

๓ं

只

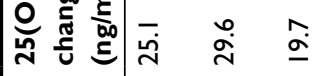

อิ

它

$\frac{n}{\frac{2}{n}}$

$\subseteq$

I

동

全

ํำ

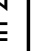

$\breve{s}$

胥

उ

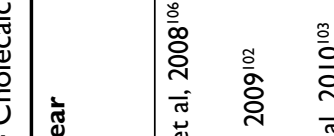

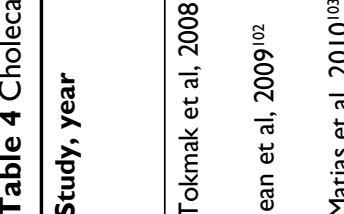

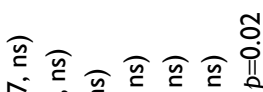

岗

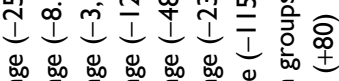

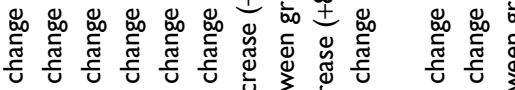

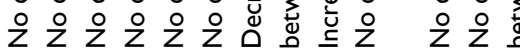

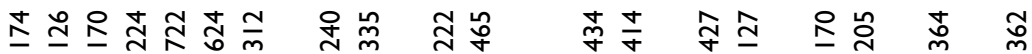

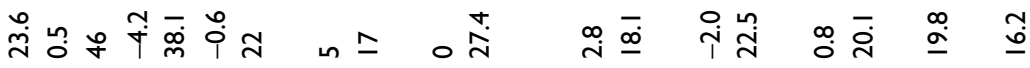

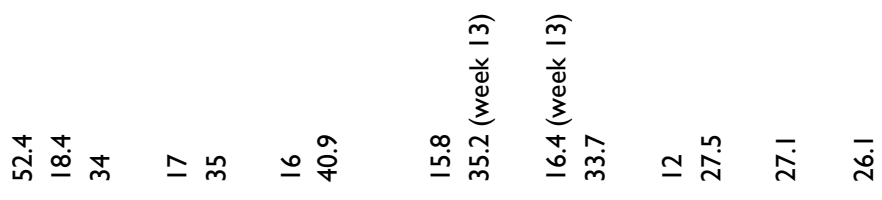

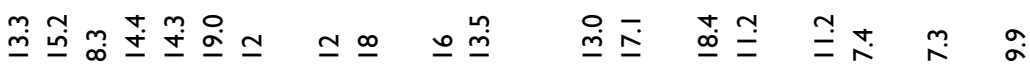
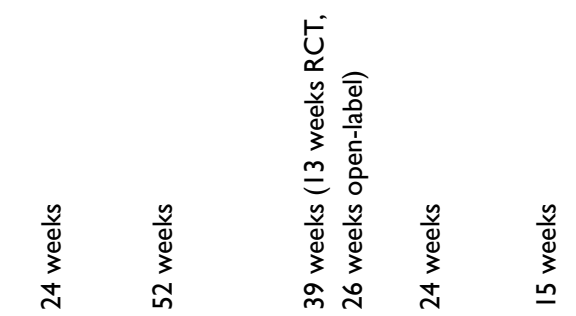

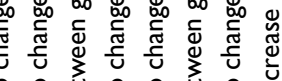

Z 2 \&

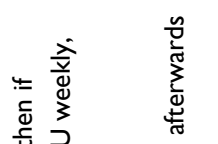

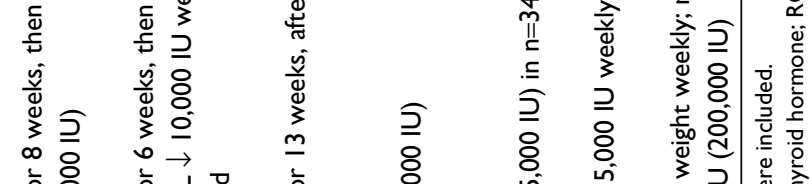

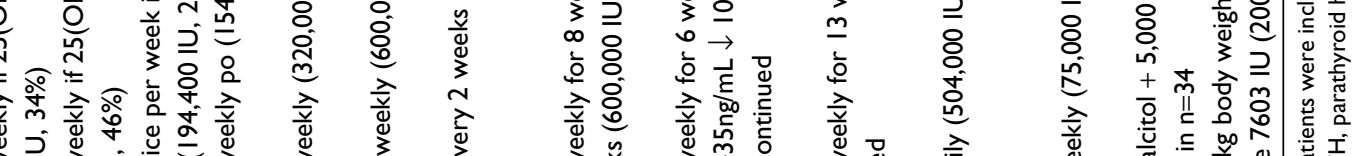

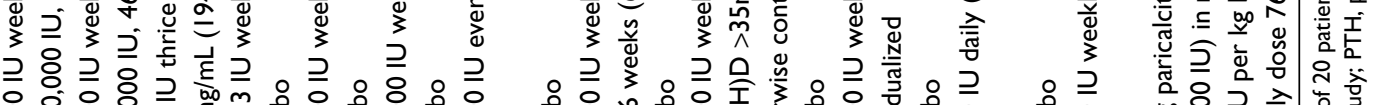

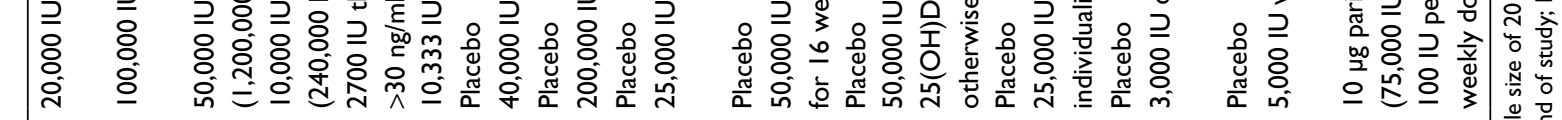

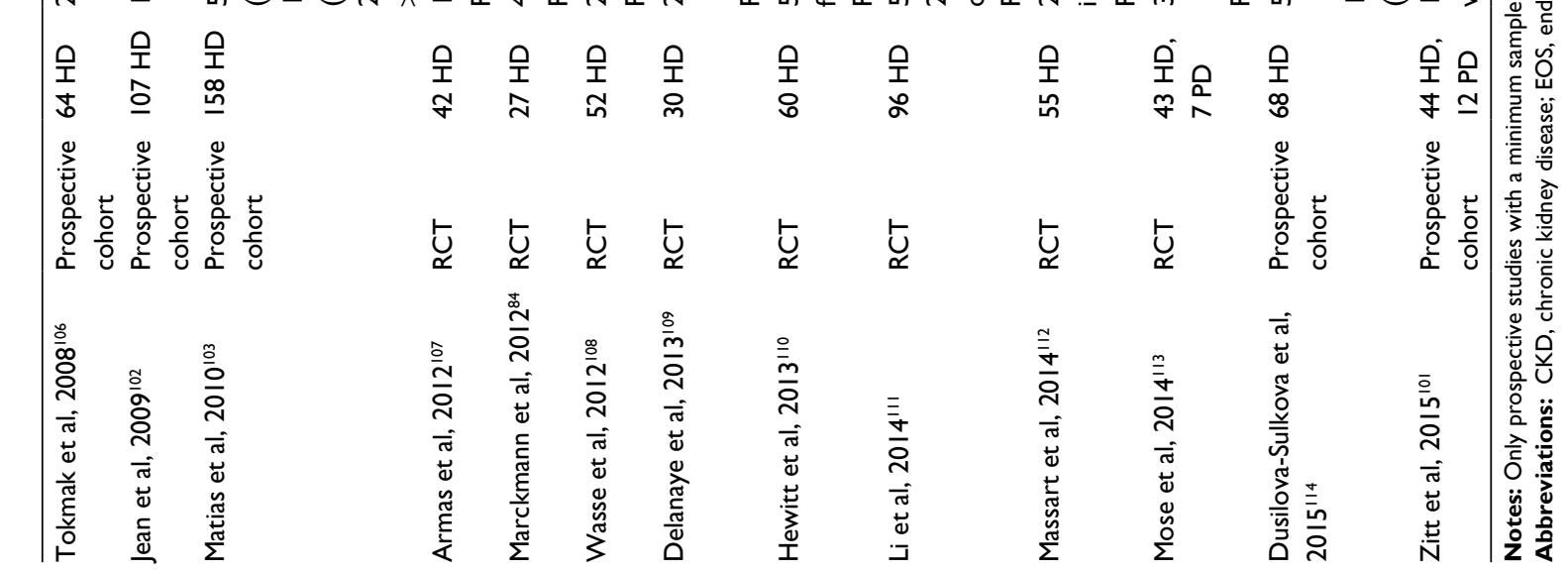


$1 \alpha$-hydroxylase is present in parathyroid tissue. ${ }^{68}$ There are no convincing data regarding the choice of vitamin $\mathrm{D}$ product or the administration route. Altogether, oral repletion seems to be more favorable compared with the intramuscular route in hemodialysis patients. Different dosing regimens in controlled and uncontrolled prospective studies have been used for both the vitamin D prohormones. Apart from fixed doses, also a body-weight-adapted dosing regimen has been recently shown to be safe and effective. ${ }^{101}$ Due to these methodological differences, the change of 25(OH)D levels and concurrent changes in PTH levels varied significantly. A detailed overview of published prospective studies investigating the effect of either cholecalciferol or ergocalciferol on PTH levels in dialysis patients is presented in Tables 4 and 5.

Although no significant changes were found in most studies, as shown in a very recent meta-analysis covering seven RCTs published during the last 5 years, ${ }^{69}$ two earlier prospective studies with larger sample size and a long treatment period found a significant PTH reduction in patients with mild to moderate sHPT. ${ }^{102,103}$ Interestingly, in both the studies also $1,25(\mathrm{OH})_{2} \mathrm{D}_{3}$ increased significantly. Although in the study by Jean et a $1^{102}$ no patient received active vitamin D treatment, $44 \%$ of patients were treated with paricalcitol at baseline in the study by Matias et al. ${ }^{103}$ In the latter one, higher $1,25(\mathrm{OH})_{2} \mathrm{D}_{3}$ levels were only found in patients without concurrent paricalcitol. In other studies, despite an increase in $1,25(\mathrm{OH})_{2} \mathrm{D}_{3}$ during the supplementation with cholecalciferol, PTH levels did not change. Obviously, the calcitriol levels, albeit higher but still far below the normal range, cannot sufficiently control sHPT. Pharmacological doses are necessary for that purpose as given with active vitamin D therapy. Nevertheless, cholecalciferol supplementation with very high doses (100,000 IU monthly) over a long period of 15 months without active vitamin $\mathrm{D}$ resulted in almost normal $1,25(\mathrm{OH})_{2} \mathrm{D}_{3}$ levels and may have thereby caused an impressive $\mathrm{PTH}$ reduction. ${ }^{102}$ Because of the significant increase in $1,25(\mathrm{OH})_{2} \mathrm{D}$ seen with the supplementation of the prohormone even in dialysis-dependent patients, one might hypothesize whether a dual therapy with an active vitamin D (calcitriol, alfacalcidol, or analogs) and a vitamin D prohomone could help to reduce the dose of the active compound. By this means, such an approach could help to attenuate its toxicity and potentially lower the risk of vascular calcification with a lower hypercalcemic and hyperphosphatemic burden. On the other hand, metabolic interactions between both compounds might become important in this situation, as the active vitamin $\mathrm{D}$ compound may downregulate $1,25(\mathrm{OH})_{2} \mathrm{D}$ production and the prohormone activate the catabolism of $1,25(\mathrm{OH})_{2} \mathrm{D}$ via the activation of 24-hydroxylase.

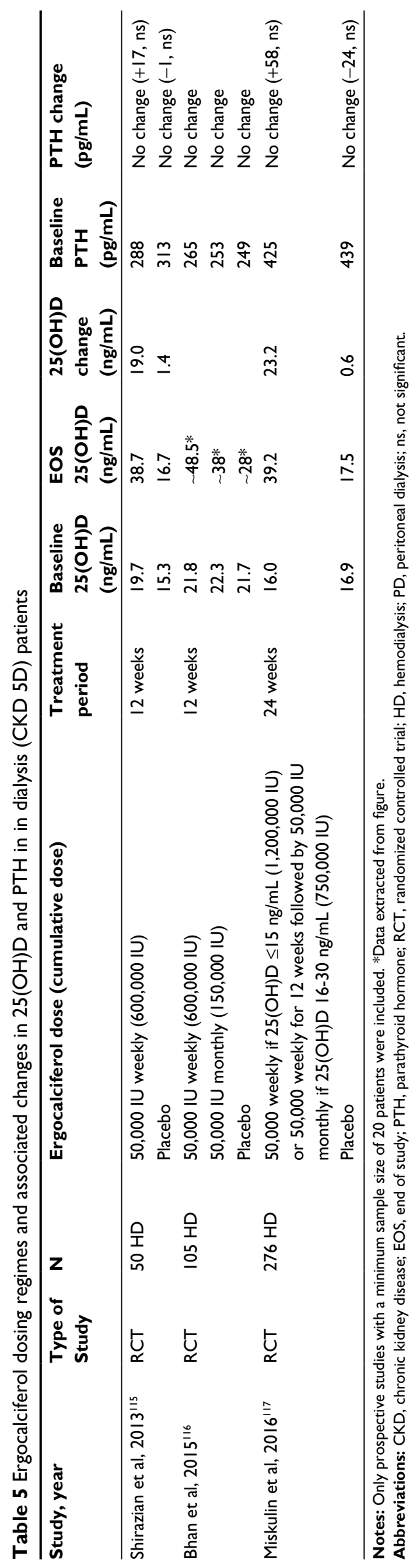

International Journal of Nephrology and Renovascular Disease 2017:10 
The efficacy of vitamin D prohormone supplementation on bone-related outcomes (such as fractures and bone pain) in CKD has not been established in high-quality studies. But such evidence is absent for all forms of vitamin D therapy. Given the available evidence by RCTs, supplementation with vitamin D prohormone has no consistent effect on PTH in patients on dialysis.

\section{Conclusion}

Vitamin D plays an important role in the development of sHPT in patients with declining renal function. These patients are characterized by a high prevalence of vitamin D insufficiency and deficiency. Supplementation with both vitamin D prohormones enables the achievement and maintenance of a normal vitamin D status when given in adequate doses over an appropriate treatment period. Although sHPT is influenced and can be successfully treated in patients with earlier stages of CKD, vitamin D prohormone supplementation seems to be of limited efficacy in patients with very late stages of CKD and those requiring dialysis. Despite all available evidence, there is still a need for high-quality RCTs determining the effect of vitamin D supplementation on sHPT with emphasis on 1) adequate supplementation protocols enabling a high proportion of patients to reach target levels, 2) identifying the target range for $25(\mathrm{OH}) \mathrm{D}$ level in $\mathrm{CKD}, 3)$ evaluating the role of a sequential compared with a combined treatment with prohormone and active compounds, and 4) collecting detailed data about $1,25(\mathrm{OH})_{2} \mathrm{D}$ and FGF23 and clinically relevant side effects.

\section{Disclosure}

The authors report no conflicts of interest in this work.

\section{References}

1. Goodman WG, Goldin J, Kuizon BD, et al. Coronary-artery calcification in young adults with end-stage renal disease who are undergoing dialysis. N Engl J Med. 2000;342(20):1478-1483.

2. Raggi P, Boulay A, Chasan-Taber S, et al. Cardiac calcification in adult hemodialysis patients. A link between end-stage renal disease and cardiovascular disease? J Am Coll Cardiol. 2002;39(4):695-701.

3. Ribeiro S, Ramos A, Brandao A, et al. Cardiac valve calcification in haemodialysis patients: role of calcium-phosphate metabolism. Nephrol Dial Transpl. 1998;13(8):2037-2040.

4. Covic A, Kothawala P, Bernal M, Robbins S, Chalian A, Goldsmith D. Systematic review of the evidence underlying the association between mineral metabolism disturbances and risk of all-cause mortality, cardiovascular mortality and cardiovascular events in chronic kidney disease. Nephrol Dial Transpl. 2009;24(5):1506-1523.

5. Malluche H, Faugere MC. Renal bone disease 1990: an unmet challenge for the nephrologist. Kidney Int. 1990;38(2):193-211.

6. Moe S, Drueke T, Cunningham J, et al. Definition, evaluation, and classification of renal osteodystrophy: a position statement from kidney disease: Improving Global Outcomes (KDIGO). Kidney Int. 2006;69(11):1945-1953.
7. De Boer IH, Gorodetskaya I, Young B, Hsu CY, Chertow GM. The severity of secondary hyperparathyroidism in chronic renal insufficiency is GFR-dependent, race-dependent, and associated with cardiovascular disease. J Am Soc Nephrol. 2002;13(11):2762-2769.

8. Levin A, Bakris GL, Molitch M, et al. Prevalence of abnormal serum vitamin $\mathrm{D}, \mathrm{PTH}$, calcium, and phosphorus in patients with chronic kidney disease: results of the study to evaluate early kidney disease. Kidney Int. 2007;71(1):31-38.

9. Isakova T, Wahl P, Vargas GS, et al. Fibroblast growth factor 23 is elevated before parathyroid hormone and phosphate in chronic kidney disease. Kidney Int. 2011;79(12):1370-1378.

10. Hu MC, Kuro-o M, Moe OW. The emerging role of Klotho in clinical nephrology. Nephrol Dial Transpl. 2012;27(7):2650-2657.

11. Malluche HH, Mawad HW, Monier-Faugere MC. Renal osteodystrophy in the first decade of the new millennium: analysis of 630 bone biopsies in black and white patients. J Bone Miner Res. 2011;26(6): 1368-1376.

12. Cunningham J, Locatelli F, Rodriguez M. Secondary hyperparathyroidism: pathogenesis, disease progression, and therapeutic options. Clin J Am Soc Nephrol. 2011;6(4):913-921.

13. Slatopolsky E, Caglar S, Pennell JP, et al. On the pathogenesis of hyperparathyroidism in chronic experimental renal insufficiency in the dog. J Clin Invest. 1971;50(3):492-499.

14. Kurosu H, Kuro OM. The Klotho gene family as a regulator of endocrine fibroblast growth factors. Mol Cell Endocrinol. 2009;299(1):72-78.

15. Hasegawa H, Nagano N, Urakawa I, et al. Direct evidence for a causative role of FGF23 in the abnormal renal phosphate handling and vitamin D metabolism in rats with early-stage chronic kidney disease. Kidney Int. 2010;78(10):975-980.

16. Taal MW, Thurston V, McIntyre NJ, Fluck RJ, McIntyre CW. The impact of vitamin D status on the relative increase in fibroblast growth factor 23 and parathyroid hormone in chronic kidney disease. Kidney Int. 2014;86(2):407-413.

17. Pavik I, Jaeger P, Ebner L, et al. Secreted Klotho and FGF23 in chronic kidney disease Stage 1 to 5: a sequence suggested from a cross-sectional study. Nephrol Dial Transpl. 2013;28(2):352-359.

18. Shimamura Y, Hamada K, Inoue K, et al. Serum levels of soluble secreted alpha-Klotho are decreased in the early stages of chronic kidney disease, making it a probable novel biomarker for early diagnosis. Clin Exp Nephrol. 2012;16(5):722-729.

19. Hu MC, Shi M, Zhang J, et al. Klotho deficiency causes vascular calcification in chronic kidney disease. J Am Soc Nephrol. 2011;22(1):124-136.

20. Lim K, Lu TS, Molostvov G, et al. Vascular Klotho deficiency potentiates the development of human artery calcification and mediates resistance to fibroblast growth factor 23. Circulation. 2012;125(18):2243-2255.

21. Lopez I, Rodriguez-Ortiz ME, Almaden Y, et al. Direct and indirect effects of parathyroid hormone on circulating levels of fibroblast growth factor 23 in vivo. Kidney Int. 2011;80(5):475-482.

22. Fan Y, Bi R, Densmore MJ, et al. Parathyroid hormone 1 receptor is essential to induce FGF23 production and maintain systemic mineral ion homeostasis. FASEB J. 2016;30(1):428-440.

23. Meir T, Durlacher K, Pan Z, et al. Parathyroid hormone activates the orphan nuclear receptor Nurr1 to induce FGF23 transcription. Kidney Int. 2014;86(6):1106-1115.

24. Galitzer H, Ben-Dov IZ, Silver J, Naveh-Many T. Parathyroid cell resistance to fibroblast growth factor 23 in secondary hyperparathyroidism of chronic kidney disease. Kidney Int. 2010;77(3):211-218.

25. Komaba H, Goto S, Fujii H, et al. Depressed expression of Klotho and FGF receptor 1 in hyperplastic parathyroid glands from uremic patients. Kidney Int. 2010;77(3):232-238.

26. Canalejo R, Canalejo A, Martinez-Moreno JM, et al. FGF23 fails to inhibit uremic parathyroid glands. J Am Soc Nephrol. 2010;21(7):1125-1135.

27. Heaney RP. Vitamin D in health and disease. Clin J Am Soc Nephrol. 2008;3(5):1535-1541. 
28. Mehrotra R, Kermah D, Budoff M, et al. Hypovitaminosis D in chronic kidney disease. Clin J Am Soc Nephrol. 2008;3(4):1144-1151.

29. Ravani P, Malberti F, Tripepi G, et al. Vitamin D levels and patient outcome in chronic kidney disease. Kidney Int. 2009;75(1):88-95.

30. LaClair RE, Hellman RN, Karp SL, et al. Prevalence of calcidiol deficiency in CKD: a cross-sectional study across latitudes in the United States. Am J Kidney dis. 2005;45(6):1026-1033.

31. Del Valle E, Negri AL, Aguirre C, Fradinger E, Zanchetta JR. Prevalence of $25(\mathrm{OH})$ vitamin D insufficiency and deficiency in chronic kidney disease stage 5 patients on hemodialysis. Hemodial Int. 2007;11(3):315-321.

32. Wolf M, Shah A, Gutierrez O, et al. Vitamin D levels and early mortality among incident hemodialysis patients. Kidney Int. 2007;72(8):1004-1013.

33. Drechsler C, Pilz S, Obermayer-Pietsch B, et al. Vitamin D deficiency is associated with sudden cardiac death, combined cardiovascular events, and mortality in haemodialysis patients. Eur Heart $J$. 2010;31(18):2253-2261.

34. Drechsler C, Verduijn M, Pilz S, et al. Vitamin D status and clinical outcomes in incident dialysis patients: results from the NECOSAD study. Nephrol Dial Transpl. 2011;26(3):1024-1032.

35. Gracia-Iguacel C, Gallar P, Qureshi AR, et al. Vitamin D deficiency in dialysis patients: effect of dialysis modality and implications on outcome. J Ren Nutr. 2010;20(6):359-367.

36. Wang AY, Lam CW, Sanderson JE, et al. Serum 25-hydroxyvitamin D status and cardiovascular outcomes in chronic peritoneal dialysis patients: a 3-y prospective cohort study. Am J Clin Nutr. 2008;87(6):1631-1638.

37. Saxena N, Gutierrez OM. Fibroblast growth factor 23, vitamin D, and health disparities among African Americans with chronic kidney disease. Semin Nephrol. 2013;33(5):448-456.

38. Holick MF. Vitamin D deficiency. NEngl JMed. 2007;357(3):266-281.

39. Thomas MK, Lloyd-Jones DM, Thadhani RI, et al. Hypovitaminosis D in medical inpatients. N Engl J Med. 1998;338(12):777-783.

40. Gonzalez EA, Sachdeva A, Oliver DA, Martin KJ. Vitamin D insufficiency and deficiency in chronic kidney disease. A single center observational study. Am J Nephrol. 2004;24(5):503-510.

41. Ghazali A, Fardellone P, Pruna A, et al. Is low plasma 25-(OH)vitamin $\mathrm{D}$ a major risk factor for hyperparathyroidism and Looser's zones independent of calcitriol? Kidney Int. 1999;55(6):2169-2177.

42. Ennis JL, Worcester EM, Coe FL, Sprague SM. Current recommended 25-hydroxyvitamin $\mathrm{D}$ targets for chronic kidney disease management may be too low. J Nephrol. 2016;29(1):63-70.

43. Norman AW. From vitamin D to hormone D: fundamentals of the vitamin D endocrine system essential for good health. Am J Clin Nutr. 2008;88(2):491S-499S.

44. Fraser DR, Kodicek E. Unique biosynthesis by kidney of a biological active vitamin D metabolite. Nature. 1970;228(5273):764-766.

45. Holick MF. Sunlight and vitamin D for bone health and prevention of autoimmune diseases, cancers, and cardiovascular disease. Am J Clin Nutr. 2004;80(6 Suppl):1678S-1688S.

46. Bouillon R, Verlinden L, Verstuyf A. Is vitamin D2 really bioequivalent to vitamin D3? Endocrinology. 2016;157(9):3384-3387.

47. Heaney RP, Recker RR, Grote J, Horst RL, Armas LA. Vitamin D(3) is more potent than vitamin $\mathrm{D}(2)$ in humans. J Clin Endocrinol Metab. 2011;96(3):E447-E452.

48. Bikle D. Vitamin D: production, metabolism, and mechanisms of action. In: De Groot LJ, Chrousos G, Dungan K, et al., editors. Endotext. South Dartmouth, MA; 2000.

49. Zhu J, DeLuca HF. Vitamin D 25-hydroxylase - four decades of searching, are we there yet? Arch Biochem Biophys. 2012;523(1):30-36.

50. Cheng JB, Levine MA, Bell NH, Mangelsdorf DJ, Russell DW. Genetic evidence that the human CYP2R1 enzyme is a key vitamin D 25-hydroxylase. Proc Natl Acad Sci U SA. 2004;101(20):7711-7715.

51. Nykjaer A, Dragun D, Walther D, et al. An endocytic pathway essential for renal uptake and activation of the steroid 25-(OH) vitamin D3. Cell. 1999;96(4):507-515.
52. Nykjaer A, Fyfe JC, Kozyraki R, et al. Cubilin dysfunction causes abnormal metabolism of the steroid hormone $25(\mathrm{OH})$ vitamin $\mathrm{D}(3)$. Proc Natl Acad Sci U S A. 2001;98(24):13895-13900.

53. Henry HL. Regulation of vitamin D metabolism. Best Pract Res Clin Endocrinol Metab. 2011;25(4):531-541.

54. Dusso AS, Brown AJ, Slatopolsky E. Vitamin D. Am J Physiol Renal Physiol. 2005;289(1):F8-F28.

55. Bouillon R, Carmeliet G, Verlinden L, et al. Vitamin D and human health: lessons from vitamin D receptor null mice. Endocr Rev. 2008;29(6):726-776.

56. Jacob AI, Sallman A, Santiz Z, Hollis BW. Defective photoproduction of cholecalciferol in normal and uremic humans. $J$ Nutr. 1984;114(7):1313-1319.

57. Krassilnikova M, Ostrow K, Bader A, Heeger P, Mehrotra A. Low dietary intake of vitamin $\mathrm{D}$ and vitamin $\mathrm{D}$ deficiency in hemodialysis patients. J Nephrol Ther. 2014;4(3):166.

58. Vaziri ND, Hollander D, Hung EK, Vo M, Dadufalza L. Impaired intestinal absorption of vitamin D3 in azotemic rats. Am J Clin Nutr. 1983;37(3):403-406.

59. Michaud J, Naud J, Ouimet D, et al. Reduced hepatic synthesis of calcidiol in uremia. JAm Soc Nephrol. 2010;21(9):1488-1497.

60. Sato KA, Gray RW, Lemann J Jr. Urinary excretion of 25-hydroxyvitamin $\mathrm{D}$ in health and the nephrotic syndrome. J Lab Clin Med. 1982;99(3):325-330.

61. Dusso AS. Kidney disease and vitamin D levels: 25-hydroxyvitamin D, 1,25-dihydroxyvitamin D, and VDR activation. Kidney Int Suppl. 2011;1(4):136-141.

62. Takemoto F, Shinki T, Yokoyama K, et al. Gene expression of vitamin D hydroxylase and megalin in the remnant kidney of nephrectomized rats. Kidney Int. 2003;64(2):414-420.

63. Perwad F, Azam N, Zhang MY, Yamashita T, Tenenhouse HS, Portale AA. Dietary and serum phosphorus regulate fibroblast growth factor 23 expression and 1,25-dihydroxyvitamin D metabolism in mice. Endocrinology. 2005;146(12):5358-5364.

64. Ritter CS, Armbrecht HJ, Slatopolsky E, Brown AJ. 25-Hydroxyvita$\min \mathrm{D}(3)$ suppresses PTH synthesis and secretion by bovine parathyroid cells. Kidney Int. 2006;70(4):654-659.

65. Halloran BP, Schaefer P, Lifschitz M, Levens M, Goldsmith RS. Plasma vitamin $\mathrm{D}$ metabolite concentrations in chronic renal failure: effect of oral administration of 25-hydroxyvitamin D3. J Clin Endocrinol Metab. 1984;59(6):1063-1069.

66. Mawer EB, Taylor CM, Backhouse J, Lumb GA, Stanbury SW. Failure of formation of 1,25-dihydroxycholecalciferol in chronic renal insufficiency. Lancet. 1973;1(7804):626-628.

67. Dusso AS, Finch J, Brown A, et al. Extrarenal production of calcitriol in normal and uremic humans. J Clin Endocrinol Metab. 1991;72(1):157-164.

68. Dusso A, Lopez-Hilker S, Rapp N, Slatopolsky E. Extra-renal production of calcitriol in chronic renal failure. Kidney Int. 1988;34(3):368-375.

69. Agarwal R, Georgianos PI. Con: nutritional vitamin D replacement in chronic kidney disease and end-stage renal disease. Nephrol Dial Transpl. 2016;31(5):706-713.

70. Kandula P, Dobre M, Schold JD, Schreiber MJ Jr, Mehrotra R, Navaneethan SD. Vitamin D supplementation in chronic kidney disease: a systematic review and meta-analysis of observational studies and randomized controlled trials. Clin JAm Soc Nephrol. 2011;6(1):50-62.

71. Trang HM, Cole DE, Rubin LA, Pierratos A, Siu S, Vieth R. Evidence that vitamin D3 increases serum 25-hydroxyvitamin D more efficiently than does vitamin D2. Am J Clin Nutr. 1998;68(4):854-858.

72. Armas LA, Hollis BW, Heaney RP. Vitamin D2 is much less effective than vitamin D3 in humans. J Clin Endocrinol Metab. 2004;89(11):5387-5391.

73. Tripkovic L, Lambert H, Hart K, et al. Comparison of vitamin D2 and vitamin D3 supplementation in raising serum 25-hydroxyvitamin D status: a systematic review and meta-analysis. Am J Clin Nutr. 2012;95(6):1357-1364. 
74. Jones KS, Assar S, Harnpanich D, et al. 25(OH)D2 half-life is shorter than 25(OH)D3 half-life and is influenced by DBP concentration and genotype. J Clin Endocrinol Metab. 2014;99(9):3373-3381.

75. Daroux M, Shenouda M, Bacri JL, Lemaitre V, Vanhille P, Bataille P. Vitamin D2 versus vitamin D3 supplementation in hemodialysis patients: a comparative pilot study. J Nephrol. 2013;26(1):152-157.

76. Wetmore JB, Kimber C, Mahnken JD, Stubbs JR. Cholecalciferol v. ergocalciferol for 25-hydroxyvitamin $\mathrm{D}(25(\mathrm{OH}) \mathrm{D})$ repletion in chronic kidney disease: a randomised clinical trial. Br J Nutr. 2016;116(12):2074-2081.

77. Houghton LA, Vieth R. The case against ergocalciferol (vitamin D2) as a vitamin supplement. Am J Clin Nutr. 2006;84(4):694-697.

78. Pilz S, Tomaschitz A, Friedl C, et al. Vitamin D status and mortality in chronic kidney disease. Nephrol Dial Transpl. 2011;26(11):3603-3609.

79. Kidney Disease: Improving Global Outcomes CKDMBDWG. KDIGO clinical practice guideline for the diagnosis, evaluation, prevention, and treatment of Chronic Kidney Disease-Mineral and Bone Disorder (CKD-MBD). Kidney Int Suppl. 2009(113):S1-S130.

80. Shroff R, Wan M, Gullett A, et al. Ergocalciferol supplementation in children with CKD delays the onset of secondary hyperparathyroidism: a randomized trial. Clin J Am Soc Nephrol. 2012;7(2):216-223.

81. Cupisti A, Vigo V, Baronti ME, D’Alessandro C, Ghiadoni L, Egidi MF. Vitamin D status and cholecalciferol supplementation in chronic kidney disease patients: an Italian cohort report. Int J Nephrol Renovasc Dis. 2015;8:151-157.

82. Dogan E, Erkoc R, Sayarlioglu H, Soyoral Y, Dulger H. Effect of depot oral cholecalciferol treatment on secondary hyperparathyroidism in stage 3 and stage 4 chronic kidney diseases patients. Ren Fail. 2008;30(4):407-410.

83. Kim SM, Choi HJ, Lee JP, et al. Prevalence of vitamin D deficiency and effects of supplementation with cholecalciferol in patients with chronic kidney disease. J Renal Nutr. 2014;24(1):20-25.

84. Marckmann P, Agerskov H, Thineshkumar S, et al. Randomized controlled trial of cholecalciferol supplementation in chronic kidney disease patients with hypovitaminosis D. Nephrol Dial Transpl. 2012;27(9):3523-3531.

85. Oksa A, Spustova V, Krivosikova Z, et al. Effects of long-term cholecalciferol supplementation on mineral metabolism and calciotropic hormones in chronic kidney disease. Kidney Blood Press Res. 2008;31(5):322-329.

86. Zisman AL, Hristova M, Ho LT, Sprague SM. Impact of ergocalciferol treatment of vitamin D deficiency on serum parathyroid hormone concentrations in chronic kidney disease. Am J Nephrol. 2007;27(1):36-43.

87. Chandra P, Binongo JN, Ziegler TR, et al. Cholecalciferol (vitamin D3) therapy and vitamin D insufficiency in patients with chronic kidney disease: a randomized controlled pilot study. Endocr Pract. 2008;14(1):10-17.

88. DeVille J, Thorp ML, Tobin L, Gray E, Johnson ES, Smith DH. Effect of ergocalciferol supplementation on serum parathyroid hormone and serum 25-hydroxyvitamin D in chronic kidney disease. Nephrology (Carlton). 2006;11(6):555-559.

89. Dreyer G, Tucker AT, Harwood SM, Pearse RM, Raftery MJ, Yaqoob MM. Ergocalciferol and microcirculatory function in chronic kidney disease and concomitant vitamin d deficiency: an exploratory, double blind, randomised controlled trial. PLoS One. 2014;9(7):e99461.

90. Gravesen E, Hofman-Bang J, Lewin E, Olgaard K. Ergocalciferol treatment and aspects of mineral homeostasis in patients with chronic kidney disease stage 4-5. Scand J Clin Lab Invest. 2013;73(2):107-116.

91. Kovesdy CP, Lu JL, Malakauskas SM, Andress DL, Kalantar-Zadeh K, Ahmadzadeh S. Paricalcitol versus ergocalciferol for secondary hyperparathyroidism in CKD stages 3 and 4 : a randomized controlled trial. Am J Kidney Dis. 2012;59(1):58-66.

92. Moe SM, Saifullah A, LaClair RE, Usman SA, Yu Z. A randomized trial of cholecalciferol versus doxercalciferol for lowering parathyroid hormone in chronic kidney disease. Clin J Am Soc Nephrol. 2010;5(2):299-306.
93. Susantitaphong P, Nakwan S, Peerapornratana S, et al. A double-blind, randomized, placebo-controlled trial of combined calcitriol and ergocalciferol versus ergocalciferol alone in chronic kidney disease with proteinuria. BMC Nephrol. 2017;18(1):19.

94. Zittermann A, Ernst JB, Gummert JF, Borgermann J. Vitamin D supplementation, body weight and human serum 25-hydroxyvitamin D response: a systematic review. Eur J Nutr. 2014;53(2):367-374.

95. Wortsman J, Matsuoka LY, Chen TC, Lu Z, Holick MF. Decreased bioavailability of vitamin D in obesity. Am J Clin Nutr. 2000;72(3):690-693.

96. Figuiredo-Dias V, Cuppari L, Garcia-Lopes MG, de Carvalho AB, Draibe SA, Kamimura MA. Risk factors for hypovitaminosis D in nondialyzed chronic kidney disease patients. J Renal Nutr. 2012;22(1):4-11.

97. Vilarrasa N, Maravall J, Estepa A, et al. Low 25-hydroxyvitamin D concentrations in obese women: their clinical significance and relationship with anthropometric and body composition variables. $J$ Endocrinol Invest. 2007;30(8):653-658.

98. Forsythe LK, Livingstone MB, Barnes MS, et al. Effect of adiposity on vitamin D status and the 25-hydroxycholecalciferol response to supplementation in healthy young and older Irish adults. Br J Nutr. 2012;107(1):126-134.

99. Garcia-Lopes MG, Pillar R, Kamimura MA, et al. Cholecalciferol supplementation in chronic kidney disease: restoration of vitamin D status and impact on parathyroid hormone. Ann Nutr Metab. 2012;61(1):74-82.

100. Wesseling-Perry K, Pereira RC, Sahney S, et al. Calcitriol and doxercalciferol are equivalent in controlling bone turnover, suppressing parathyroid hormone, and increasing fibroblast growth factor-23 in secondary hyperparathyroidism. Kidney Int. 2011;79(1):112-119.

101. Zitt E, Sprenger-Mahr H, Mundle M, Lhotta K. Efficacy and safety of body weight-adapted oral cholecalciferol substitution in dialysis patients with vitamin D deficiency. BMC Nephrol. 2015;16:128.

102. Jean G, Souberbielle JC, Chazot C. Monthly cholecalciferol administration in haemodialysis patients: a simple and efficient strategy for vitamin D supplementation. Nephrol Dial Transpl. 2009;24(12):3799-3805.

103. Matias PJ, Jorge C, Ferreira C, et al. Cholecalciferol supplementation in hemodialysis patients: effects on mineral metabolism, inflammation, and cardiac dimension parameters. Clin JAm Soc Nephrol. 2010; 5(5):905-911.

104. Alvarez JA, Law J, Coakley KE, et al. High-dose cholecalciferol reduces parathyroid hormone in patients with early chronic kidney disease: a pilot, randomized, double-blind, placebo-controlled trial. Am J Clin Nutr. 2012;96(3):672-679.

105. Thimachai P, Supasyndh O, Chaiprasert A, Satirapoj B. Efficacy of high vs. conventional ergocalciferol dose for increasing 25-hydroxyvitamin $\mathrm{d}$ and suppressing parathyroid hormone levels in stage III-IV CKD with vitamin D deficiency/insufficiency: a randomized controlled trial. J Med Assoc Thai. 2015;98(7):643-648.

106. Tokmak F, Quack I, Schieren G, et al. High-dose cholecalciferol to correct vitamin D deficiency in haemodialysis patients. Nephrol Dial Transpl. 2008;23(12):4016-4020.

107. Armas LA, Andukuri R, Barger-Lux J, Heaney RP, Lund R. 25-Hydroxyvitamin $\mathrm{D}$ response to cholecalciferol supplementation in hemodialysis. Clin J Am Soc Nephrol. 2012;7(9):1428-1434.

108. Wasse H, Huang R, Long Q, Singapuri S, Raggi P, Tangpricha V. Efficacy and safety of a short course of very-high-dose cholecalciferol in hemodialysis. Am J Clin Nutr. 2012;95(2):522-528.

109. Delanaye P, Weekers L, Warling X, et al. Cholecalciferol in haemodialysis patients: a randomized, double-blind, proof-of-concept and safety study. Nephrol Dial Transpl. 2013;28(7):1779-1786.

110. Hewitt NA, O'Connor AA, O'Shaughnessy DV, Elder GJ. Effects of cholecalciferol on functional, biochemical, vascular, and quality of life outcomes in hemodialysis patients. Clin J Am Soc Nephrol. 2013; 8(7):1143-1149.

111. Li L, Lin M, Krassilnikova M, et al. Effect of cholecalciferol supplementation on inflammation and cellular alloimmunity in hemodialysis patients: data from a randomized controlled pilot trial. PLoS One. 2014;9(10):e109998. 
112. Massart A, Debelle FD, Racape J, et al. Biochemical parameters after cholecalciferol repletion in hemodialysis: results from the vitadial randomized trial. Am J Kidney Dis. 2014;64(5):696-705.

113. Mose FH, Vase H, Larsen T, et al. Cardiovascular effects of cholecalciferol treatment in dialysis patients--a randomized controlled trial. BMC Nephrol. 2014;15:50.

114. Dusilova-Sulkova S, Safranek R, Vavrova J, Horacek J, Pavlikova L, Palicka V. Low-dose cholecalciferol supplementation and dual vitamin D therapy in haemodialysis patients. Int Urol Nephrol. 2015;47(1):169-176.
115. Shirazian S, Schanler M, Shastry S, et al. The effect of ergocalciferol on uremic pruritus severity: a randomized controlled trial. J Renal Nutr. 2013;23(4):308-314.

116. Bhan I, Dobens D, Tamez H, et al. Nutritional vitamin D supplementation in dialysis: a randomized trial. Clin J Am Soc Nephrol. 2015;10(4):611-619.

117. Miskulin DC, Majchrzak K, Tighiouart H, et al. Ergocalciferol supplementation in hemodialysis patients with vitamin D deficiency: a randomized clinical trial. J Am Soc Nephrol. 2016;27(6): 1801-1810.
The International Journal of Nephrology and Renovascular Disease is an international, peer-reviewed open access journal focusing on the pathophysiology of the kidney and vascular supply. Epidemiology, screening, diagnosis, and treatment interventions are covered as well as basic science, biochemical and immunological studies. The manuscript management system is completely online and includes a very quick and fair peer-review system, which is all easy to use. Visit http://www. dovepress.com/testimonials.php to read real quotes from published authors.

Submit your manuscript here: https://www.dovepress.com/international-journal-of-nephrology-and-renovascular-disease-journal 